\title{
Carbohydrate feeding of piglets weaned at 10 days. Eliects of lactose from whey ultrafiltrate and of maltodextrine on piglet performances and apparent digestibility of the diet
}

\author{
B. SEVEE, C. FÉVRIER and A. AUMAITRE \\ Station de Recherches sur l'Élevage des Porcs, I. N. R. A., C. N.R. Z., \\ 78350 Jouy en Josas
}

The feeding value of three carbohydrate sources incorporated into a dry pelleted milk replacer for piglets weaned at Io days was studied in a trial comprising I 20 animals from 20 litters. The animals were distributed into groups according to a balanced incomplete blozks design of the type I ( $\mathrm{r}$ experimental unit $=2$ piglets ; I block $=$ three littermate pairs ; I replication $=2$ contemporary litters) allowing comparison of 6 treatments.

Group I (control) received a "Ist age control feed " based on skimmilk. The $2 / 3$ of the latter were replaced by an association of soluble fish protein concentrate (SFPC 80) and the carbohydrate sources studied in the experimental diets : maltodextrine (group 2); maltodextrine (50 p. Ioo) + dried whey ultrafiltrate ( 50 p. Ioo) (group 3 ); ultrafiltrate (group 4); ultrafiltrate (50 p. IOO) + pure lactose (50 p. Ioo) (group 5) and pure lactose (group 6). The " 2 nd age feed" (barley, soyabean oil-meal, herring meal) was offered from the age of 28 days and totally replaced the "I st age feed" two weeks later.

The corrected growth performances showed that the "maltodextrine diet " $(67 \mathrm{~g} / \mathrm{day})$ was slightly inferior to the control diet ( $77 \mathrm{~g} / \mathrm{day}$ ) during the postweaning period (10-28 days). This effect became less marked during the following period and the analysis of results obtained at the age of $4^{2}$ days did not reveal any significant difference to be imputed to the carbohydrates studied. However, analysis of the final results recorded at the age of 63 days showed a significant delay in the growth of group 6 (pure lactose) which may be imputed to a pooreradaptation of the animals to the " and age feed".

During the period between I4-2I days of age, the apparent digestibility of the diet was lower in the experimental groups than in the control group (ADC of the dry matter $=80.2$ and 83.4 , nitrogen $=73.7$ and 80.8$)$. These differences disappeared during the following periods $(2 \mathrm{I}-42$ days) as regards the apparent digestibility coefficient (ADC) of the dry matter and organic matter. On the other hand, the ADC of nitrogen in the control group (88.2) remained higher than that of the maltodextrine diet $(84.8)$; the experimental diets based on lactose gave intermediate values (85.9). However, the great variability of these results, especially during the initial period, does not permit to cnsure statistically these results at the level $\mathrm{P}<0.05$.

On the other hand, all the results show that a high level of dried whey ultrafiltrate ( $34 \mathrm{p}$. Ioo) is well accepted by the piglets and that the utilization of maltodextrine is as favourable as that of lactose in the "Ist age feed $»$. Furthermore, at the age of 9 weeks, comparison between the performances of groups 2 and 4 ( $292 \mathrm{~g} /$ day) and those of the control group $(302 \mathrm{~g} /$ day) indicates that when using a soluble fish protein concentrate (SFPC 80), a level of 25 p. Ioo skimmilk is sufficient in the milk replacer for piglets weaned at io days. 